Vol. 23, 1985, pp. $393-398$

\title{
A Continuous Method for the Determination of Leucine Aminopeptidase in Human Serum with $L$-Leucinamide as Substrate
}

\author{
By J. C. M. Hafkenscheid and B. E. M. Kohler \\ Laboratory for Clinical Chemistry, Department of Internal Medicine, St. Radboud Hospital, \\ University of Nijmegen, Nijmegen, The Netherlands
}

(Received November 12, 1984/February 25, 1985)

\begin{abstract}
Summary: A continuous procedure for the determination of leucine aminopeptidase is described. $L$-leucinamide is used as substrate and the liberated ammonia is determined with the glutamate dehydrogenase reaction. The enzyme is $\mathrm{Mn}^{2+}$-activated and $30 \mu \mathrm{mol} / 1 \mathrm{MnCl}_{2}$ is necessary for an optimal activity measurement. Influence of buffer type, buffer concentration and $\mathrm{pH}$ are reported together with the apparent $K_{\mathrm{m}}$ values of leucine aminopeptidase for $L$-leucinamide and of glutamate dehydrogenase for 2-oxoglutarate. Amastatin, a potent inhibitor, inhibits the reaction of leucine aminopeptidase completely, whereas it has no inhibitory effect on the reaction with glutamate dehydrogenase. The normal reference interval for leucine aminopeptidase is $12-65 \mathrm{U} / 1$ at $37^{\circ} \mathrm{C}$. The properties of the enzyme are discussed.
\end{abstract}

\section{Eine kontinuierliche Methode zur Bestimmung von Leucinaminopeptidase in menschlichem Serum}

Zusammenfassung: Es wurde ein kontinuierliches Verfahren zur Bestimmung von Leucinaminopeptidase mit $L$-Leucinamid als Substrat untersucht. Das freigesetzte Ammoniak wird mit der GlutamatdehydrogenaseReaktion bestimmt. Das Enzym wird aktiviert von $\mathrm{Mn}^{2+}$ und $30 \mu \mathrm{mol} / 1$ von $\mathrm{MnCl}_{2}$ ist für eine optimale Aktivität erforderlich. Der Einfluß von Art des Puffer, Pufferkonzentration und pH wird zusammen mit dem scheinbaren $K_{\mathrm{m}}$-Wert von Leucinaminopeptidase für $L$-Leucinamid und von Glutamatdehydrogenase für 2Oxoglutarat beschrieben. Amastatin hemmt Leucinaminopeptidase vollständig, während es keine hemmende Wirkung auf die Glutamatdehydrogenase-Reaktion hat. Der Referenzbereich beträgt $12-65 \mathrm{U} / 1$ bei $37^{\circ} \mathrm{C}$. Die Eigenschaften des Enzyms werden diskutiert.

\section{Introduction}

Leucine aminopeptidase ( $\alpha$-aminoacyl-peptide hydrolase (cytosol); EC 3.4.11.1) is a zinc-metalloenzyme, which occurs in tissues and body fluids of all organisms. It was first crystallized from bovine lens (1) and afterwards purified from hog kidney (2), swine kidney (3) and human liver (4).

The enzyme is able to hydrolyse $L$-peptides, releasing a single amino acid from the $\mathrm{N}$-terminus of the peptide chain. $\bar{L}$-Leucinamide is a suitable substrate for the enzyme. Different methods for the determination of the catalytic activity concentration of leucine aminopeptidase have been described. The leucine formed from $L$-leucinamide after hydrolysis is determined by paper chromatography (5) or the liberated ammonia is measured according to Berthelot $(6,7)$ or by titration (8). Until now no continuous monitoring procedure for the determination of leucine aminopeptidase in serum has been described, except for a method using leucine dehydrogenase ( $L$-leucine: $\mathrm{NAD}^{+}$oxidoreductase (deaminating) EC 1.4.1.9) as indicator enzyme (9).

In the present paper a continuous method is reported, in which the ammonia liberated after hydrolysis of $L$ leucinamide by leucine aminopeptidase is determined according to the following reaction scheme: 
$L$-leucinamide $\rightleftarrows L$-leucine $+\mathrm{NH}_{3}$

2-oxoglutarate $+\mathrm{NH}_{3}+\mathrm{NADPH}+\mathrm{H}^{+} \rightarrow$ L-glutamate + NADP+

The equilibrium of the indicator reaction with glutamate dehydrogenase ( $L$-glutamate: $\mathrm{NAD}(\mathrm{P})^{+}$ oxidoreductase (deaminating) EC 1.4.1.3) lies far to the right, so that changes in absorbance at $340 \mathrm{~nm}$ are directly proportional to the concentration of ammonia. The principle of this reaction has been described previously $(10-12)$.

The results of our study leading to the development of a continuous procedure for the determination of leucine aminopeptidase are presented.

\section{Materials and Methods}

All determinations were carried out at $37^{\circ} \mathrm{C}$ on a Multistat III microcentrifugal analyser (Instrumentation Laboratory, IJsselstein, The Netherlands). The final reaction mixture for leucine aminopeptidase contained per liter: triethanolamine (pH 8.2) $90 \mathrm{mmol}, \mathrm{MnCl}_{2} 30 \mu \mathrm{mol}, 2$-oxoglutarate $14.3 \mathrm{mmol}$, NADPH $300 \mu \mathrm{mol}$, ADP $1.4 \mathrm{mmol}$, glutamate dehydrogenase $0.047 \mathrm{~g}$ and $L$-leucinamide $100 \mathrm{mmol}$. Sample $(6 \mu \mathrm{l})$ was added to $93 \mu \mathrm{l}$ of reaction mixture containing triethanolamine, $\mathrm{MnCl}_{2}$, 2-oxoglutarate, NADPH, ADP and glutamate dehydrogenase. After standing at room temperature for 10 min the rotor was placed in the analyser. The preincubation time at $37^{\circ} \mathrm{C}$ was 10 min. After starting the reaction with $63 \mu \mathrm{l}$ of $L$-leucinamide the decrease in absorbance was read every $30 \mathrm{~s}$ from $2 \mathrm{~min}$ until 5 min after the beginning of the reaction.

In testing the different parameters all other conditions for the reaction rate determinations were held constant.

Blood was taken by venipuncture and promptly centrifuged: the sera were stored at $4{ }^{\circ} \mathrm{C}$ and assayed as soon as possible. All catalytic activity concentrations are expressed in U/1.

$L$-Leucinamide and amastatin were purchased from Sigma, Brunschwig, Amsterdam, The Netherlands, and glutamate dehydrogenase from beef liver $(100 \mathrm{mg} / 10 \mathrm{ml})$ from Boehringer, Mannheim, FRG. All other chemicals were reagent grade.

In the statistical analysis we used Student's t-test for paired observations.

\section{Results and Discussion}

Figure 1 shows the time dependence of the enzymatic reaction. A linear relationship was observed up to 5 min after starting the reaction with $L$-leucinamide. Reagent blank and sample blank are also given and these are always subtracted from the determination before the catalytic activity concentrations are calculated.

Figure 1 shows also the reaction rate as a function of the amount of sample added. The reaction is linear up to $500 \mathrm{U} / 1$ and samples with higher activities have to be diluted with saline. Table 1 shows the effect of various bivalent cations on the catalytic activity. It is obvious that addition of $\mathrm{Mn}^{2+}$ ions increases the activity concentration by about $17 \%$, whereas the addition of $\mathrm{Mg}^{2+}$ and $\mathrm{Fe}^{2+}$ ions showed only a very small effect. $\mathrm{Zn}^{2+}$ ions inhibit the activity concentration very slightly. $\mathrm{Co}^{2+}$ ions have a stimulatory effect on the glutamate dehydrogenase activity (own observation), so the effect of $\mathrm{Co}^{2+}$ on the leucine aminopeptidase activity could not be determined.

Preincubation of serum with $\mathrm{Mn}^{2+}$ in the presence of all other reagents except $L$-leucinamide gave a catalytic activity concentration that was $10 \%$ higher than that obtained by incubation of serum with $\mathrm{Mn}^{2+}$ alone $(129.0 \pm 62.8 \mathrm{U} / 1$ and $118.1 \pm 69.3 \mathrm{U} / 1 \mathrm{re}-$ spectively; $\mathrm{n}=17 ; \mathrm{p}<0.05$ ). Therefore we preincubated the serum with $\mathrm{Mn}^{2+}$ ions in the total reagent mixture without $L$-leucinamide in all our determinations.

In figure 2 the effect of various concentrations of $\mathrm{Mn}^{2+}$ on the determination of leucine aminopeptidase is given. From $25 \mu \mathrm{mol} / 1$ to $100 \mu \mathrm{mol} / \mathrm{l} \mathrm{Mn}^{2+}$ ions no further increase of the catalytic activity was observed. We chose a concentration of $30 \mu \mathrm{mol} / \mathrm{l}$ $\mathrm{Mn}^{2+}$ ions in our standard procedure.

Table 2 shows the effect of different buffers on the catalytic activity concentration of leucine aminopeptidase. The highest activity concentration was obtained with triethanolamine, which was therefore chosen as the assay buffer. In comparison, for example, borate buffer gives only $60 \%$ of the activity concentration observed in triethanolamine. Figure 3 shows the dependency of the catalytic activity concentration on the ionic strength of the buffer triethanolamine. The catalytic activity did not change significantly when the buffer concentration was varied between about 80 and $300 \mathrm{mmol} / \mathrm{l}$. We chose a concentration of $90 \mathrm{mmol} / 1$ triethanolamine.

The $\mathrm{pH}$ dependency of the catalytic activity of leucine aminopeptidase is given in figure 4 . The highest activity concentration was obtained at $\mathrm{pH} 8.2$ in a buffer system of $90 \mathrm{mmol} / \mathrm{l}$ triethanolamine. It is obvious that at this $\mathrm{pH}$ the combination of both enzymes, leucine aminopeptidase and glutamate dehydrogenase, gives the highest activity concentration. Therefore, no comparison can be made with the $\mathrm{pH}$ optimum of leucine aminopeptidase from serum (6) or from human liver (4). Figure 5 shows the relation between $v$ and $v /[\mathrm{S}]$ for leucine aminopeptidase, when the concentration of the substrate $L$-leucinamide is varied. The mean apparent $K_{\mathrm{m}}$ value obtained from the slope of this line is $6.60 \pm 1.27 \mathrm{mmol} / \mathrm{l}$ for 6 determinations in comparison with $K_{\mathrm{m}}$ values obtained for two different leucine aminopeptidase 

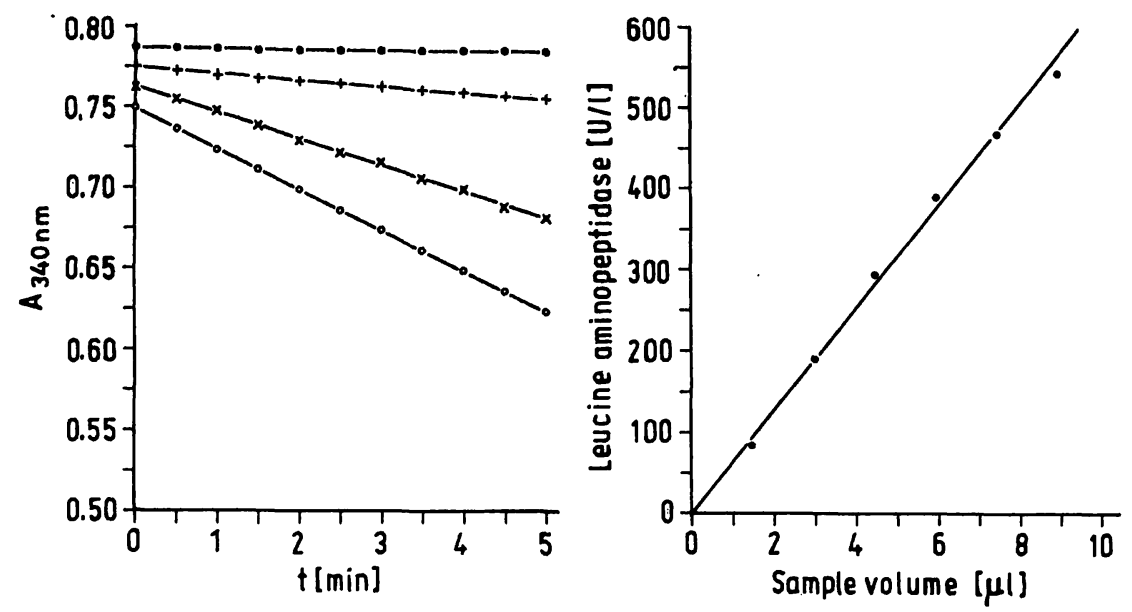

Fig. 1. Left: Time dependence of leucine aminopeptidase determination in serum.

- o sample blank

+-+ reagent blank

$x-x$ and 0 - 2 sera.

Right: Reaction rate as a function of the amount of sample added for leucine aminopeptidase assay in serum. (Mean of 4 determinations).

Tab.1. Effect of various cations on the catalytic activity concentration of leucine aminopeptidase $(\mathrm{n}=14)$. $\mathrm{Fe}^{2+}$ and $\mathrm{Zn}^{2+}$ were added as sulphates, other ions as chlorides. All differences are significant $(p<0.05)$ except between 1 and 2 .

\begin{tabular}{ll}
\hline $\begin{array}{l}\text { Ions added } \\
(30 \mu \mathrm{mol} / \mathrm{l})\end{array}$ & $\begin{array}{l}\text { Catalytic concentration } \\
(\mathrm{U} / \mathrm{l})\end{array}$ \\
\hline- & $188.3 \pm 64.1$ \\
$\mathrm{Mg}^{2+}$ & $191.8 \pm 65.1$ \\
$\mathrm{Fe}^{2+}$ & $194.1 \pm 65.5$ \\
$\mathrm{Zn}^{2+}$ & $179.9 \pm 63.3$ \\
$\mathrm{Mn}^{2+}$ & $220.6 \pm 82.8$ \\
\hline
\end{tabular}
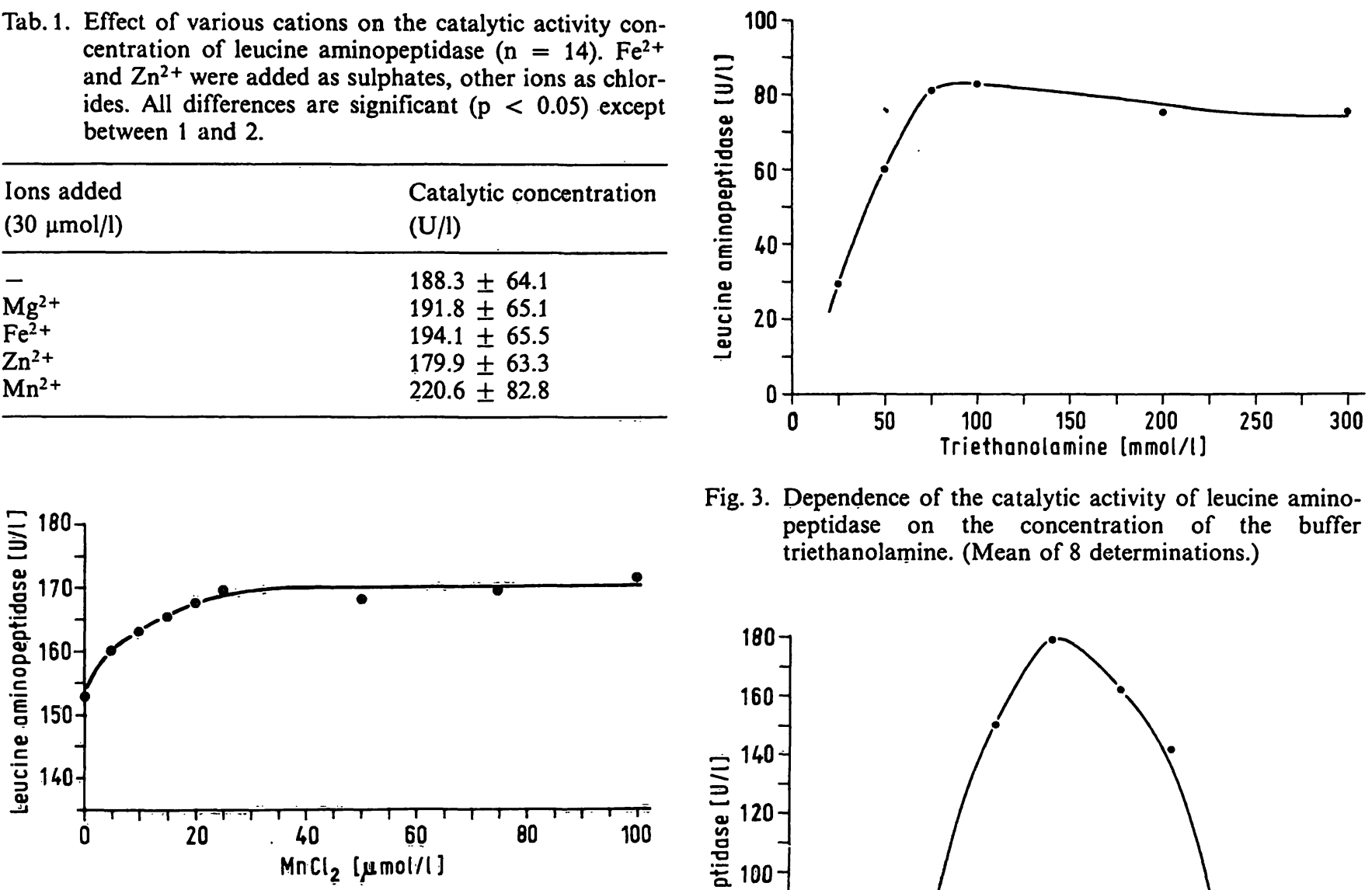

Fig. 2. Influence of $\mathrm{Mn}^{2+}$ on the determination of leucine aminopeptidase in serum. (Mean of '5 determinations).

Tab.2. Effect of various buffer systems on the leucine aminopeptidase determination in serum $(n=7)$. All differences are significant $(p<0.05)$.

\begin{tabular}{ll}
\hline Buffer & Catalytic concentration \\
$(150 \mathrm{mmol} / \mathrm{l})$ & $(\mathrm{U} / \mathrm{l})$ \\
\hline Triethanolamine & $73.6 \pm 29.1$ \\
Tris & $64.1 \pm 24.6$ \\
Borate & $45.5 \pm 13.6$ \\
\hline
\end{tabular}

Fig. 3. Dependence of the catalytic activity of leucine aminopeptidase on the concentration of the buffer triethanolamine. (Mean of 8 determinations.)

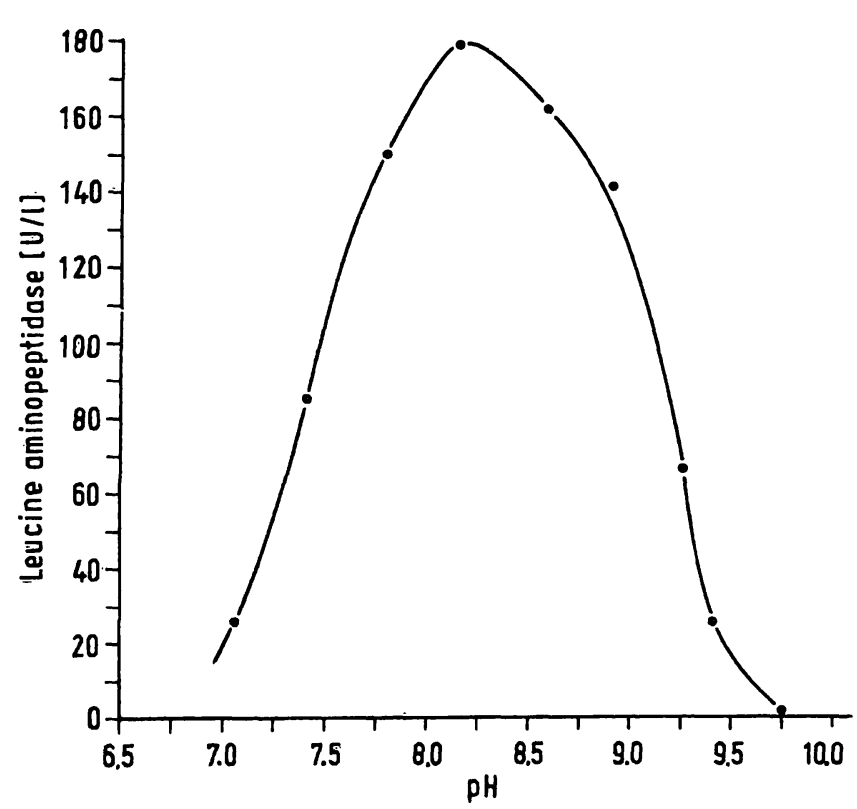

Fig. 4. Effect of $\mathrm{pH}$ on the leucine aminopeptidase activity of serum. (Mean of 5 determinations.) 


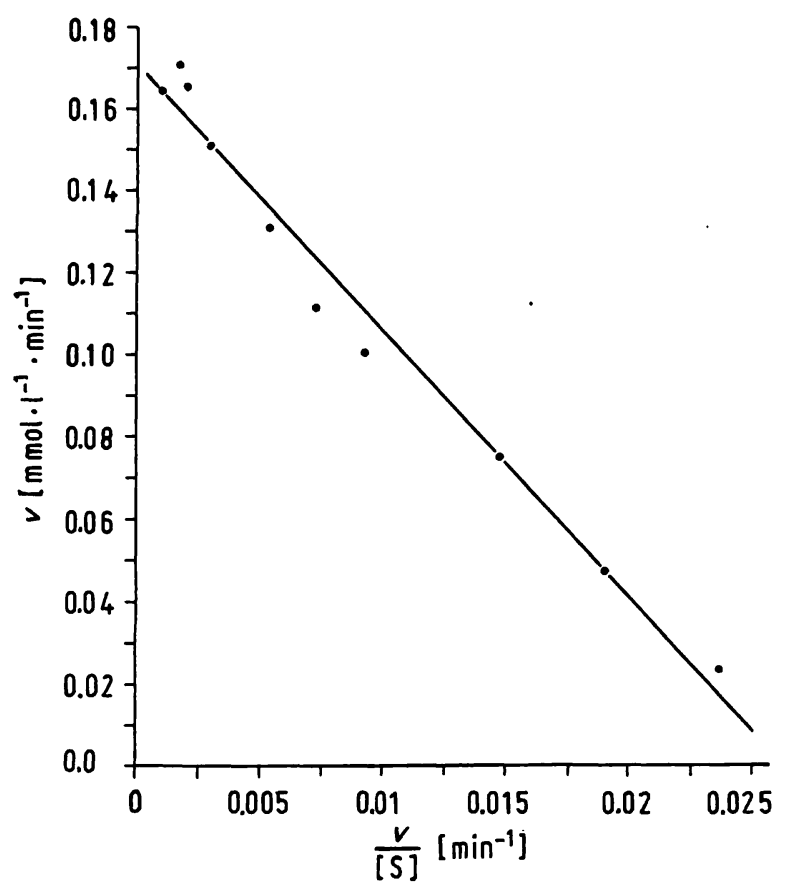

Fig. 5. Reaction rate of leucine aminopeptidase as a function of the concentration of $L$-leucinamide. (Mean of $6 \mathrm{de}$ terminations.)

fractions from pig kidney of 5.21 and $15.7 \mathrm{mmol} / \mathrm{l}$ (13) or from human liver of 7.7 or $10.5 \mathrm{mmol} / \mathrm{l}$ (4). In all our experiments we used a final substrate concentration of $100 \mathrm{mmol} / \mathrm{l}$ (approximately 15-times the apparent $K_{\mathrm{m}}$ value) which resulted in a zero-order rate reaction.

The effect of variation of the concentration of NADPH is given in figure 6. It is obvious that no catalytic activity can be measured at concentrations of NADPH less than $50 \mu \mathrm{mol} / \mathrm{l}$. We added $300 \mu \mathrm{mol} / \mathrm{l}$ NADPH to the standard reaction mixture.

ADP is necessary for stabilisation of the indicator enzyme glutamate dehydrogenase and increases the rate of conversion of $\mathrm{NH}_{3}$ considerably (11). We added always $1.4 \mathrm{mmol} / \mathrm{l} \mathrm{ADP}$ to the reaction mixture, which is sufficient for optimal reaction rates (fig. 7).

The influence of increasing amounts of 2oxoglutarate on the reaction rate is given in figure 8. The apparent $K_{\mathrm{m}}$ value of glutamate dehydrogenase for 2-oxoglutarate can be calculated from the slope of this line. The choice of $14.3 \mathrm{mmol} / \mathrm{l}$ of 2 oxoglutarate in the final reaction mixture ensures adequate substrate saturation at more than 10 times the apparent $K_{\mathrm{m}}$ value of $0.52 \pm 0.05 \mathrm{mmol} / \mathrm{l}$. This value agrees with the apparent $K_{\mathrm{m}}$ value of $0.7 \mathrm{mmol} / 1$ obtained by Humphries et al. (14).

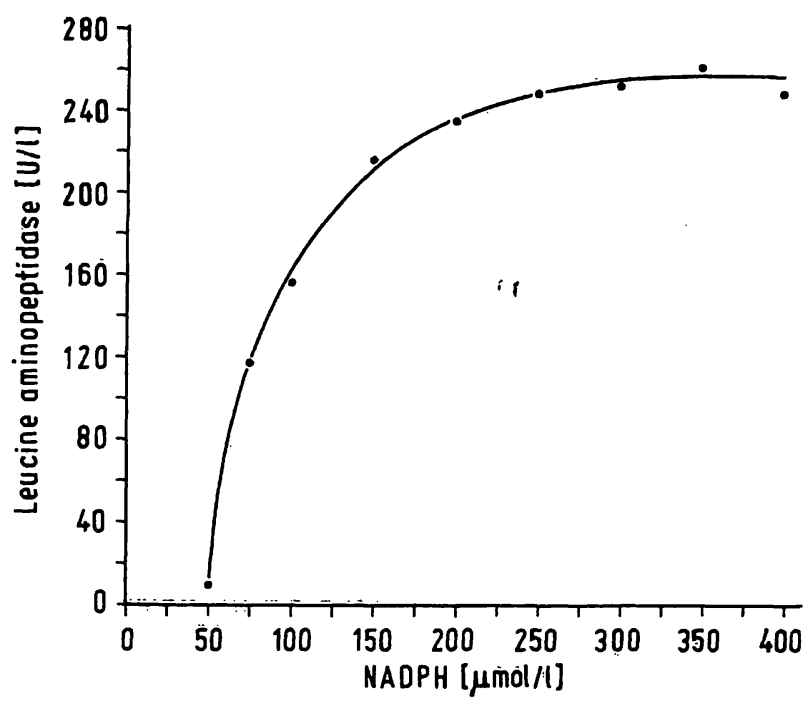

Fig. 6. Reaction rate of leucine aminopeptidase as a function of the concentration of NADPPH. (Mean of 7 determinations.)

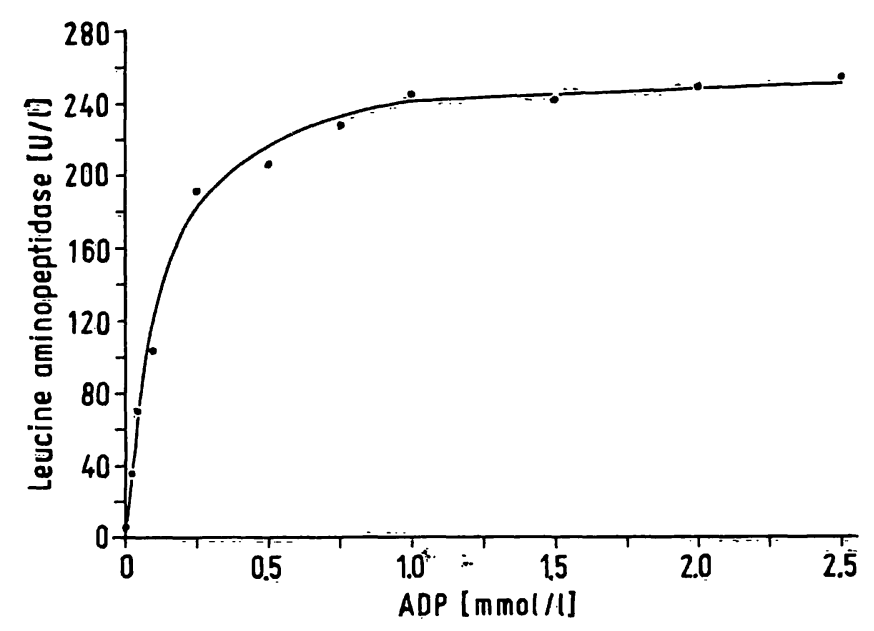

Fig. 7. Effect of addition of ADP on the catalytic activity concentration of leucine aminopeptidase. (Mean of 5 determinations.)

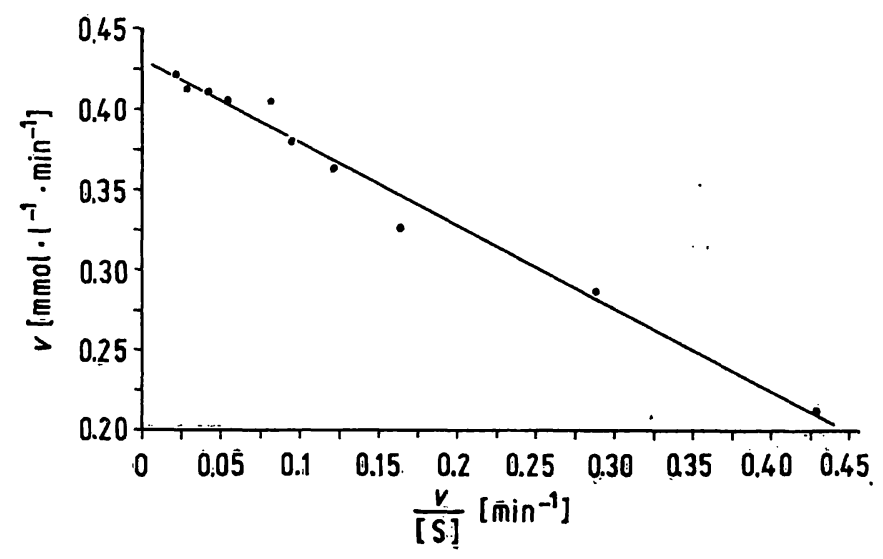

Fig. 8. Reaction rate of leucine aminopeptidase as a function of the concentration of 2-oxoglutarate. (Mean of 7 determinations.) 
The influence of the addition of glutamate dehydrogenase to the reaction mixture is given in figure 9. Increasing amounts of glutamate dehydrogenase enhance the reaction rate of leucine aminopeptidase. We chose $47 \mathrm{mg} / \mathrm{l}$ glutamate dehydrogenase, which is sufficient for an optimal reaction rate.

The dependence of the measured catalytic activity concentration of leucine aminopeptidase on the relation between sample and total assay volume is seen in figure 10. There is an increase of the catalytic activity concentration up to a volume fraction of 0.03 , and a decrease at higher volume fractions. For practical reasons we chose a volume fraction of sample of 0.037 , which is about $2 \%$ lower than that required for maximal catalytic activity concentration.

The within-day and between-day variabilites are given in table 3 . Generally these results are satisfactory.

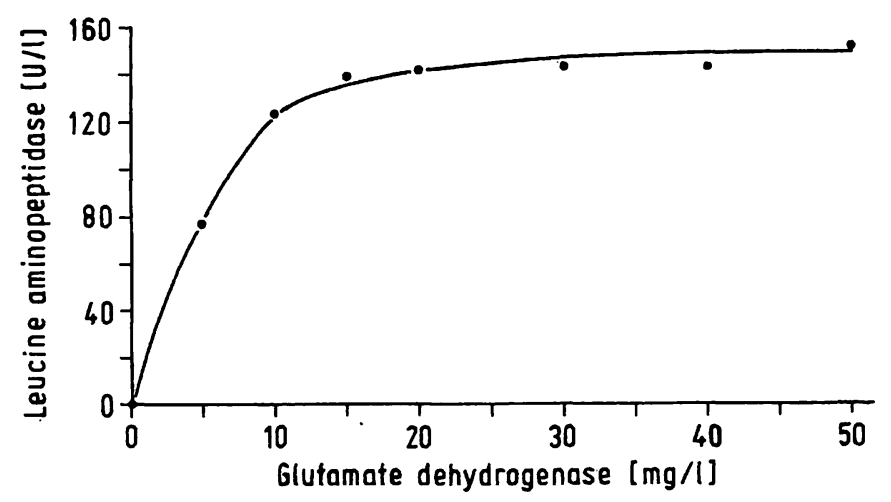

Fig. 9. Influence of the addition of glutamate dehydrogenase on the reaction rate of leucine aminopeptidase. (Mean of 7 determinations.)

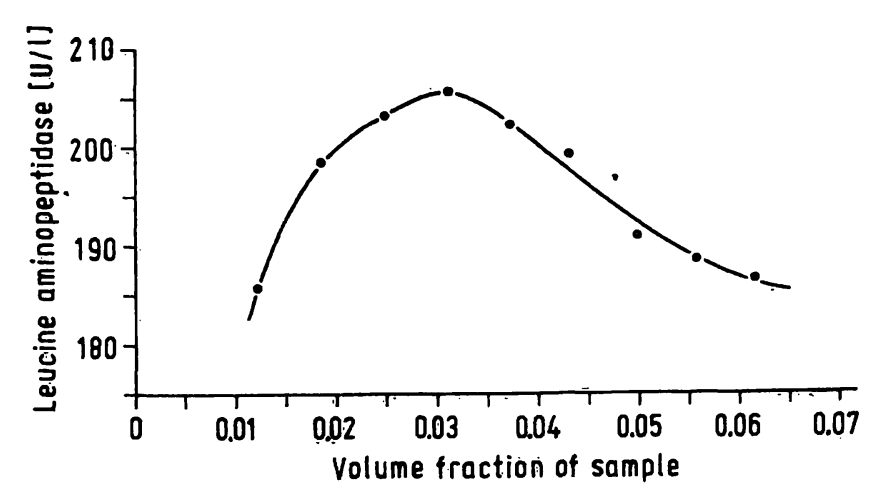

Fig. 10. Relationship between the catalytic concentration of leucine aminopeptidase and the volume fraction of sample. (Mean of 4 determinations.)
Tab. 3. Within-day and between-day variability of leucine aminopeptidase.

\begin{tabular}{llll}
\hline $\begin{array}{l}\text { Within-day } \\
(\mathrm{U} / \mathrm{l})\end{array}$ & $\begin{array}{l}\mathrm{CV} \\
(\%)\end{array}$ & $\begin{array}{l}\text { Between-day } \\
(\mathrm{U} / \mathrm{l})\end{array}$ & $\begin{array}{l}\mathrm{CV} \\
\mathrm{n}=5\end{array}$ \\
$\mathrm{n}=5$ & & $82.9 \pm 5.3$ & \\
\hline $78.3 \pm 1.4$ & 1.8 & $159.7 \pm 4.1$ & 6.4 \\
$141.9 \pm 2.0$ & 1.4 & $191.9 \pm 7.1$ & 3.7 \\
$181.2 \pm 2.8$ & 1.5 & & \\
\hline
\end{tabular}

We carried out all our determinations at $37^{\circ} \mathrm{C}$. The temperature converting factor from $37^{\circ} \mathrm{C}$ to $30^{\circ} \mathrm{C}$ was $0.614 \pm 0.068$ for 55 determinations.

Amastatin is a well known inhibitor of leucine aminopeptidase because it binds to cell surfaces and therefore inhibits cell-surface aminopeptidases (15). Addition of $25 \mu \mathrm{mol} / 1$ of amastatin to the reaction mixture inhibits the enzyme completely. Amastatin has no inhibitory effect on the glutamate dehydrogenase reaction; $\left(30.2 \pm 11.3 \mu \mathrm{mol} / 1 \mathrm{NH}_{3}\right.$ in the absence of amastatin and $33.6 \pm 7.0 \mu \mathrm{mol} / \mathrm{l}$ in its presence; $\mathrm{n}=5 ; \mathrm{p}>0.40$ ).

Leucine aminopeptidase activity concentrations were determined in sera from 144 healthy people. The normal reference interval (mean \pm 2 S.D.) was $12-65 \mathrm{U} / 1$ at $37^{\circ} \mathrm{C}$.

Based on the determination of ammonia described by da Fonsec $a$-Wollheim $(10,11)$, a continuously monitoring procedure has thus been designed for the determination of leucine aminopeptidase. Most of the parameters of this method are related to the properties of glutamate dehydrogenase, the indicator enzyme of the reaction scheme. But these parameters are also compatible with the measurement of the catalytic activity concentration of leucine aminopeptidase by this method.

It is difficult to distinguish leucine aminopeptidase from amino acid arylamidase ( $\alpha$-aminoacyl-peptide hydrolase (microsomal) EC 3.4.11.2), although the first enzyme occurs in the cytosol of the cells and the second one is microsomal. These two enzymes show different substrate specificities. Leucine aminopeptidase hydrolyses leucine-peptides as well as $L$ leucinamide, while amino acid arylamidase splits preferentially alanine from peptides, amides and 4nitroanilides; but this substrate specificity is not absolute. From studies by Niiobe \& Fujii (16) it is obvious that an enzyme preparation of leucine aminopeptidase purified from human liver is able to split $L$-alanyl- $\beta$-naphthylamide and a purified enzyme preparation of amino acid arylamidase hydrolyses $L$ - 
leucinamide. Generally it is accepted that $L$ leucinamide is the preferred substrate for leucine aminopeptidase originating from tissues or serum.

Plaquet et al. (6) described in normal and pathological human sera two enzymes, which are able to split $L$ leucinamide. The "alkaline enzyme" has a $\mathrm{pH}$ optimum of 9.0 and is activated by $\mathrm{Mg}^{2+}$ ions, while the second enzyme ("neutral enzyme"), has an optimal activity at $\mathrm{pH} 7.8$ and is inhibited by $\mathrm{Mg}^{2+}$ ions. The reference value for the "alkaline enzyme" is $1.2 \mathrm{U} / 1$ at $37^{\circ} \mathrm{C}$. A comparison between the proper-

\section{References}

1. Glässer, D. \& Hanson, H. (1963) Naturwissenschaften 50 , 595-596.

2. Spackman, D. H., Smith, E. L. \& Brown, D. M. (1955) J. Biol. Chem. 212, 255-269.

3. Ledeme, N., Hennon, G., Vincent-Fiquet, O. \& Plaquet, R. (1981) Biochim. Biophys. Acta 660, 262-270.

4. Ledeme, N., Vincent-Fiquet, O., Hennon, G. \& Plaquet, R. (1983) Biochimie 65, 397-404.

5. Hanson, H., Glässer, D. \& Kirschke, H. (1965) HoppeSeyler's Z. Physiol. Chem. 340, 107-125.

6. Plaquet, R., Ledeme, N., Vincent-Fiquet, O. \& Biserte, G. (1973) Clin. Chim. Acta 46, 91-103.

7. Tamura, Y., Niinobe, M., Arima, T., Okuda, H. \& Fujii, S. (1973) Biochim. Biophys. Acta 327, 437-445.

8. Hafkenscheid, J. C. M. (1984) In: Methods of Enzymatic Analysis (Bergmeyer, H. U., ed.) $3^{\text {rd }}$ Edition; Volume V, pp. 5-10. ties of the enzymes described by us and by Plaquet et al. (6) is difficult, because we determined the kinetic properties of leucine aminopeptidase in relation to the properties of the indicator enzyme glutamate dehydrogenase. It seems that the enzymes are distinct, since our enzyme is $\mathrm{Mn}^{2+}$ activated and the reference value is much higher.

The clinical value of the leucine aminopeptidase is not exactly known. The relation between leucine aminopeptidase and amino acid arylamidase is now under investigation.

9. Takamiya, S., Ohshima, T., Tanizawa, K. \& Soda, K. (1983) Anal. Biochem. 130, 266-270.

10. da Fonseca-Wollheim, F. (1973) Z. Klin. Chem. Klin. Biochem. 11, 421-425.

11. da Fonseca-Wollheim, F. (1973) Z. Klin. Chem. Klin. Biochem. 11, 426-431.

12. van Anken, H. C. \& Schiphorst, M. E. (1974) Clin. Chim. Acta $56,151-157$.

13. Bryce, G. F. \& Rabin, B. R. (1964) Biochem. J. 90, $509-512$.

14. Humphries, B. A., Melnychuk, M., Donegan, E. J. \& Snee, R. D. (1979) Clin. Chem. 25, 26-30.

15. Rich, D. H., Moon, B. J. \& Harbeson, S. (1984) J. Med. Chem. 27, 417-422.

16. Niiobe, M. \& Fujii, S. (1980) J. Biochem. 87, 195-203.

Dr. J. C. M. Hafkenscheid Laboratory for Clinical Chemistry Department of Internal Medicine

St. Radboud Hospital

University of Nijmegen

P.O. Box 9101

NL-6500 HB Nijmegen 